\title{
A Review of the Surface Modifications for Corrosion Mitigation of Steels in Lead and LBE
}

\author{
Jean-Bernard Vogt * (D) and Ingrid Proriol Serre
}

Univ. Lille, CNRS, INRAE, Centrale Lille, UMR 8207-UMET—Unité Matériaux Et Transformations, 59000 Lille, France; ingrid.proriol-serre@univ-lille.fr

* Correspondence: jean-bernard.vogt@centralelille.fr

\begin{abstract}
The review paper starts with the applications of liquid metals and then concentrates on lead and lead-bismuth eutectic used in Gen IV nuclear reactors and accelerator-driven systems. Key points of degradation modes of austenitic stainless steels and ferritic-martensitic steels, candidates for the structural components, are briefly summarized. Corrosion and liquid metal embrittlement are critical issues that must be overcome. Next, the paper focuses on the strong efforts paid to the mitigation of corrosion and reviews the different solutions proposed for the protection of steels in lead and leadbismuth eutectic. There exist promising solutions based on protection by deposition of protective coatings or protection by "natural" oxidation resulting from optimized chemical composition of the steels. However, the solutions have to be confirmed especially by longer-term experiments and by additional mechanical testing.
\end{abstract}

Keywords: liquid metal; oxidation; dissolution; coating deposition process; AFA steel; martensitic steel; austenitic steel; lead-bismuth eutectic

check for updates

Citation: Vogt, J.-B.; Proriol Serre, I. A Review of the Surface Modifications for Corrosion Mitigation of Steels in Lead and LBE. Coatings 2021, 11, 53. https:// doi.org/10.3390/coatings11010053

Received: 24 November 2020 Accepted: 2 January 2021 Published: 6 January 2021

Publisher's Note: MDPI stays neutral with regard to jurisdictional clai$\mathrm{ms}$ in published maps and institutional affiliations.

Copyright: (C) 2021 by the authors. Licensee MDPI, Basel, Switzerland. This article is an open access article distributed under the terms and conditions of the Creative Commons Attribution (CC BY) license (https:// creativecommons.org/licenses/by/ $4.0 /)$.

\section{Introduction}

Liquid metal, elemental or alloyed material, is a special state of matter which gives rise to particular engineering applications. The melting temperature and the temperature range in which the material is in the liquid state depend on its chemical composition. Depending on the melting temperature, different engineering applications arise. It may be considered that low melting temperature materials are metals or alloys with a melting point below $300{ }^{\circ} \mathrm{C}$. Among them gallium and mercury and their alloys are liquid or nearly liquid at room temperature. They have potential applications as nanomaterials [1] as well as spallation neutron sources, e.g., [2,3]. Higher melting point materials such as sodium, lithium, tin, lead, bismuth (the three last metals being heavy liquid metalsHLMs), and their alloys have found application in soldering for the electronic industry, in cooling concentrated solar power systems [4,5], nuclear reactors [6-8], and also for neutron sources [9]. Properties of HLMs and their impact on the behavior of materials or components in contact have been investigated since the 1950s, but are still today the purpose of research.

The present review paper concentrates on lead and Lead-Bismuth Eutectic (LBE), an alloy containing $44.5 \mathrm{wt} . \% \mathrm{~Pb}$ and $55.5 \mathrm{wt} . \% \mathrm{Bi}$, which are the favorite candidate HLMs as the cooling fluids for Gen IV nuclear reactors [10]. Performances of $\mathrm{Pb}-\mathrm{Bi}-\mathrm{Sn}$ and $\mathrm{Pb}-\mathrm{Bi}-\mathrm{Zn}$ alloys with lower melting temperatures have been compared to that of LBE. However, they appeared to be more aggressive at high temperature against steels than LBE, and therefore were no longer investigated [6]. As mentioned in the literature (e.g., [11-15]), lead and LBE have a low melting point (respectively very close to 327 and $125^{\circ} \mathrm{C}$ ) and a high boiling point (respectively close to 1745 and $1670{ }^{\circ} \mathrm{C}$ ) which allows working at high temperature. Moreover, thanks to the inertness with air and water, it is highlighted that its use makes a lead or LBE-cooled reactor safe. In addition, LBE appears as a good lubricant with a low friction coefficient of 0.1 and a wear rate of $10^{-6} \mathrm{~mm}^{3} / \mathrm{Nm}$ for the steel discs [16]. 
The expected operating temperatures of lead and LBE reactors range from 300 to $550{ }^{\circ} \mathrm{C}$, depending on the specific technology. Therefore, degradation of structural materials in contact with these HLMs may occur. Two families of steels were identified to be employed for components in contact with them: $9 \%-12 \% \mathrm{Cr}$ martensitic steels and austenitic stainless steels. In addition to the higher amount of chromium in their chemical composition, austenitic stainless steels contain also a large quantity of nickel. The chemical composition of these alloys has been designed and are now well approved even if continuous research is still going on to improve some of the use properties. Both steel families are sensitive to liquid lead and LBE, but they react differently as well in terms of corrosion as in terms of mechanical resistance.

The corrosion phenomena have been very well described and summarized by Fazio and Balbaud in Ref. [17]. The corrosion mechanisms in LBE or lead depend on the chemical composition of the steel, the oxygen content in the liquid metal, and the temperature. In addition, corrosion degradation can be accelerated by the velocity of the metal liquid [18-20]. It is generally referred to the Ellingham diagram to estimate the corrosion mechanism, an example of which is shown in Figure 1.

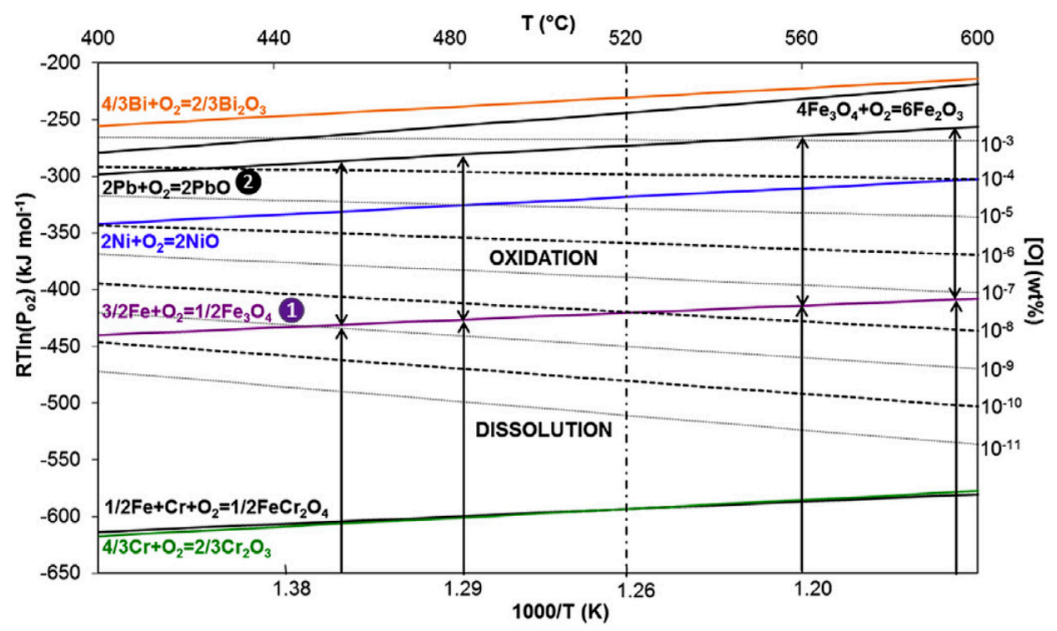

Figure 1. Ellingham diagram for the 316L alloy (i.e., element activities are equal to the molar fractions of the elements in the 316L alloy) in Lead-Bismuth Eutectic (LBE) from [21].

In saturated oxygen lead or LBE, the mechanism of corrosion is oxidation for both families of steels. Oxidation kinetics and mechanisms are now well documented for 316L stainless steels and for T91 martensitic steel in the range of $450-500{ }^{\circ} \mathrm{C}[20,22-24]$. Oxidation kinetics is parabolic with an oxidation rate lower for 316L steel than for T91 steel. The oxide layer exhibits a duplex scale, consisting of an inner spinel and an outer magnetite. The layer thickness grows faster for the magnetite oxide than for the spinel oxide [25]. Austenitic stainless steels are much less sensitive to oxidation [26] and sometimes claimed as excellent corrosion resistance materials [27]. Nevertheless, it is important to note that the external magnetic layer and the oxide layer easily crack under stress, as shown in the scanning electron microscopy (SEM) image of Figure 2 [28].

In low oxygen liquid metals, austenitic stainless steels corrode by selective dissolution of nickel in the liquid metal, which may result in the local transformation of austenite into ferrite in the depleted surface zones, as shown in Figure 3 [29]. For instance, in stagnant LBE for $1000 \mathrm{~h}$ at $450{ }^{\circ} \mathrm{C}$, the threshold oxygen concentration associated with the onset of dissolution corrosion in $316 \mathrm{~L}$ steel lies between $10^{-6}$ and $10^{-7}$ mass $\%$ oxygen for the specific exposure conditions [30]. Not only the chemical composition but also the initial state of the material influence the dissolution [21,31,32]. Cold-worked 316L are more sensitive to ferritization [31] and exhibit more severe dissolution corrosion [32] than solution-annealed 316L steels. The velocity of lead alloys impacts the corrosion rate of 316L steel which becomes much higher from a velocity of $2 \mathrm{~m} / \mathrm{s}$ [17]. 


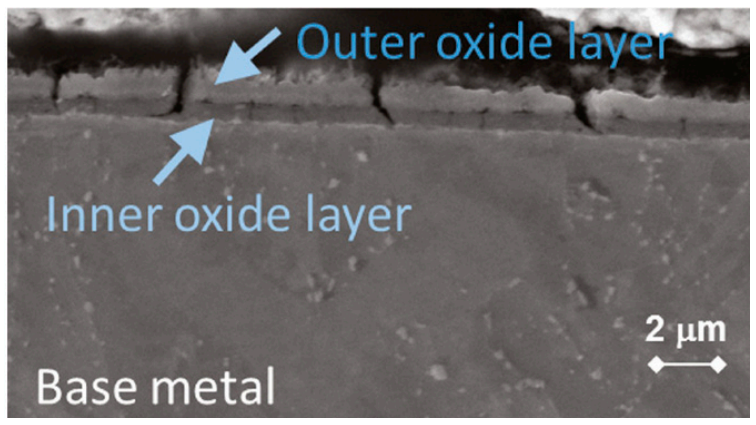

Figure 2. Double-layer oxide scale developed and braked in T91 steel under constant extension rate test in $\mathrm{Pb}$ at $400{ }^{\circ} \mathrm{C}$, showing many superficial cracks in the oxide; SEM-secondary electrons image from [28].

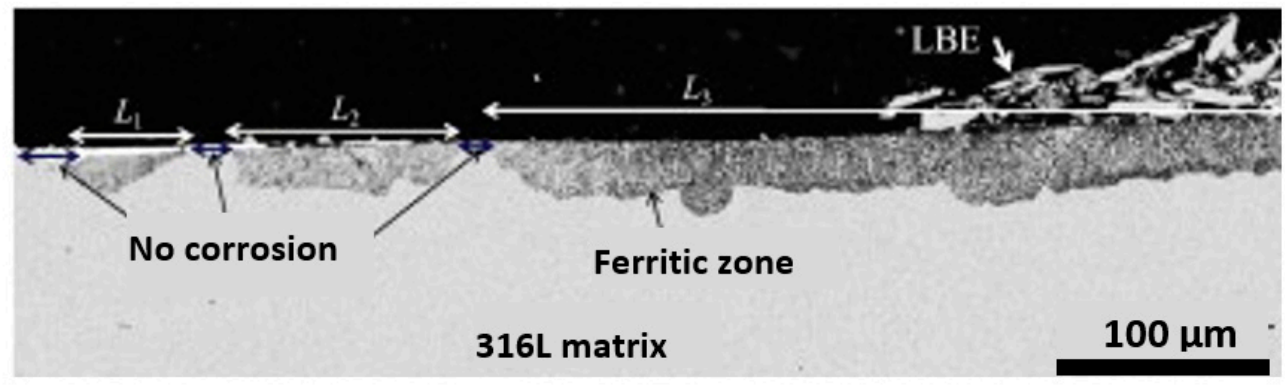

Figure 3. SEM cross-section image showing ferritic zones in stainless steel sample after $3045 \mathrm{~h}$ at $500{ }^{\circ} \mathrm{C}$ in $10^{-8}$ wt. $\%$ oxygen LBE, from [29]. $L_{1}, L_{2}$ and $L_{3}$ are the length of the ferritic layer.

For martensitic steels, homogeneous dissolution occurs promoting more (e.g., [18,33]) or less pronounced relief which may act further as a stress raiser, see Figure 4.

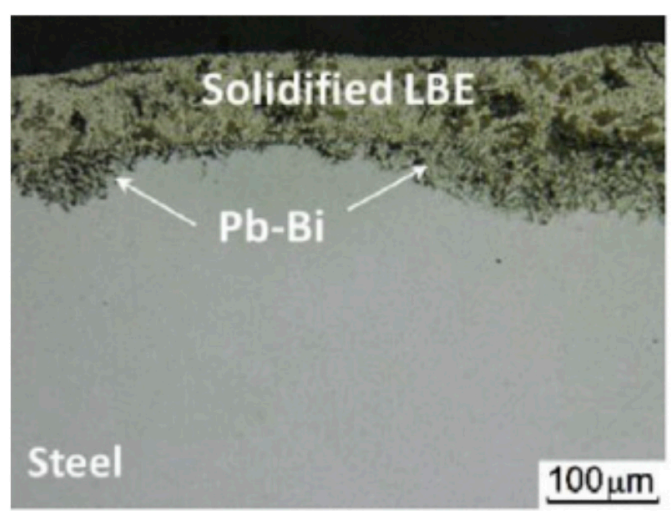

Figure 4. Transversal cross-section of T91 steel tested in static LBE $\left(10^{-8}\right.$ mass $\%$ oxygen $)$ at $550{ }^{\circ} \mathrm{C}$ for $1525 \mathrm{~h}$, from [33].

Martinelli et al. [34] showed that for T91 steel in very low oxygen (near $10^{-13} \mathrm{wt} . \%$ ) LBE, dissolution is linear as a function of time as well as in a static condition, as in dynamics conditions. However, the dissolution rate is controlled by natural convection and by both the interfacial reaction and diffusion controls, respectively.

However, regarding the mechanical response, austenitic stainless steels remain ductile when stressed in lead and in LBE. These alloys see their performances slightly decrease under cyclic loading. Fatigue crack initiation occurs earlier in liquid metal than in air under high cyclic strain $[35,36]$. The mechanical response of martensitic steel is much more sensitive to the liquid metal environment. T91 steel may exhibit liquid metal embrittlement (LME) e.g., [28,33,37,38], have fatigue lives e.g., [35,39-41], and creep rupture times [42-44] 
are shorter in liquid metal than in air. It is important to note that LME and fatigue cracking initiate in liquid metals at the surface of the materials, as does corrosion.

Therefore, in order to mitigate the corrosion damage of steels by lead or LBE, intensive research on the surface modifications of materials in contact with liquid metals has been conducted and is still in progress.

The present paper is a literature review of the different solutions proposed these last two decades for the protection of steels in liquid metals. The results mainly come from the investigations carried out in international projects devoted to liquid metal-cooled nuclear reactors. T91 and 12Cr martensitic steels, 316L austenitic stainless steels, or more highly alloys steels are mainly considered. In this research, attention is essentially paid to the corrosion resistance of these steels in liquid lead or/and LBE.

\section{Technical Options}

Since corrosion, LME or fatigue crack initiation start at the external surface of the material, it turns out that their modification has to be optimized to overcome or delay the related damages.

Two options have been considered and are still under consideration:

- The deposition of an external coating on the steel matrix.

- An "auto-formation" of an external layer whose composition depends on the chemical composition of the steel matrix and the reaction with the liquid metal.

Both solutions consist in setting a barrier between the steel matrix and the liquid metal in order to prevent interaction between them. In addition to corrosion resistance functions, the protective barrier is required to be adhesive to the steel substrate and mechanically performant. In the case of the degradation of the coating, the degradation must not be transferred to the steel substrate, e.g., must not reduce fatigue resistance. Therefore, the thickness of the coating must be controlled or the coating must exhibit auto repairing properties, e.g., reformation of a stable oxide in the liquid metal.

Within these two above options, there is one which consists in forming a stable and protective layer of iron and chromium oxides at the surface of stainless steels by maintaining the steel in an oxygen rich liquid metal in appropriate conditions range. This option is not recommended for high temperature applications (above $500{ }^{\circ} \mathrm{C}$ ) because the kinetics of oxide growth is fast. This would result in a thick and weakly adherent layer of oxide $[45,46]$. Thus, reduction in thermal conductivity, oxide spallation, and channel plugging are arising issues.

In chromium-containing steels such as stainless steels, chromia $\left(\mathrm{Cr}_{2} \mathrm{O}_{3}\right)$, a protective chromium oxide surface layer, forms spontaneously at the steel surface. The idea to form such a stable and protective oxide layer from the metallic elements beside chromium of steel, independently of the level of oxygen present in the liquid metal, is one solution. Thus, the candidate elements are those for which, regardless of the oxygen content, a stable oxide forms, that is, aluminum, silicon, and titanium.

Depending on the selected element, other obstacles will have to be overcome. For instance, the selection of aluminum to form the oxide (here $\mathrm{Al}_{2} \mathrm{O}_{3}$, alumina) imposes precisely tuning the chemical composition of the steel. Indeed, it needs to add a minimum content of $\mathrm{Al}$ to form the alumina scale and at the same time to maintain the austenitic phase of the matrix, since aluminum is a ferrite promoter.

The protection by deposition of an external coating may overcome the problem of the local depletion of chemical elements. Moreover, the chemical formulation of the coating is much more open, so that one can adjust it to optimize both the corrosion and mechanical resistance of the coating. However, the coating process can require operating at a high temperature or under mechanical stress, which can lead to the modification not only of the surface of the material but also of the bulk. For the latter, an additional heat treatment may become necessary to recover the initial microstructure of the material.

The corrosion resistance was the first step in the selection of a solution. In general, this was assessed by static or dynamic immersion of the material in the liquid metal 
for imposed durations with control of temperature and chemistry of the liquid metal especially oxygen content. If the proposed solution fulfils the requirement for corrosion resistance, additional investigation should follow. As mentioned above, it must be verified if the corrosion resistance of the protected material estimated in free mechanical loading conditions is maintained under external loading. Especially, it is necessary to investigate if undesirable and unforeseen effects such as LME may occur. This is vital to guarantee the life time of the structure, since it will be subjected to loading by pure mechanical stresses or thermal stresses.

\section{Coatings Formed by Deposition of Foreign Chemical Elements at the External Surface}

Coatings elaborated by different research laboratories to counter corrosion in lead and LBE will be presented next. They differ in their composition and deposit process.

\subsection{Aluminized Coatings by Pack Cementation}

Pack cementation is a widely used chemical vapor deposition (CVD) technique. The traditional pack consists of four components: the substrate to be coated, the masteralloy powder, the halide salt activator, and the inert filler. The process takes place within a heat-resistant retort which may involve a temperature high enough so that the microstructure of the substrate can be modified unintentionally.

Deloffre et al. [47] studied the performances of different aluminized coatings deposited by pack cementation on T91 and 316L steels for corrosion protection in dynamic conditions. The process normally involved a diffusion phase at $900{ }^{\circ} \mathrm{C}$. However, in order to avoid any effect on the microstructure of T91 steel, they performed the Fe-Al deposition on the steel at a processing temperature lower than the tempering temperature. The coating on the 316L steel had a thickness between 50 and $100 \mu \mathrm{m}$. It consisted of two layers, an external layer that contains $\mathrm{Al}, \mathrm{Fe}, \mathrm{Cr}, \mathrm{Ni}$, and $\mathrm{O}$ with a high $\mathrm{Al}$ content and an inner layer with less $\mathrm{Al}$ but richer in $\mathrm{Cr}$. Between the two layers, precipitates rich in $\mathrm{Ni}$ and $\mathrm{Al}$ were found. The T91 steel exhibited different coatings in nature as as well in thickness (between 50 and $100 \mu \mathrm{m})$ in relation with the different employed processes.

For both steels, and for all coating processes, adequate protection was obtained in static conditions for low oxygen concentrations (for which dissolution of the unprotected steels occurs) for temperatures up to $500{ }^{\circ} \mathrm{C}$ and long durations (1000 h). No weight change of the specimen as well as no modification in the thickness and composition of the coating were observed. At $600{ }^{\circ} \mathrm{C}$ and for low oxygen concentrations (below $10^{-8} \mathrm{wt} . \%$ ), significant damages of the coatings occurred for both T91 and 316L steels leading to severe corrosion of the materials. For higher oxygen concentrations, no damage of the coating was observed for the test duration of $1000 \mathrm{~h}$. However, the researchers concluded that the aluminized coating on 316L steel was quite sensitive to a dynamic flow, due to erosion when tested in loops.

\subsection{Iron Aluminide, Iron Boride, and an Iron Solid Solution Enriched in Chromium and Covered by Carbide by Pack Cementation}

Ledoux et al. undertook their pack cementation expertise approved on nickel base alloys [48] to the T91 martensitic steel. They elaborated iron aluminide, iron boride, and an iron solid solution enriched in chromium and covered by carbide coatings by pack cementation. The mechanical behavior at $300{ }^{\circ} \mathrm{C}$ in LBE of each coated T91 steel was studied $[49,50]$. First, it was checked that the integrity of the T91 steel was not impacted by the coating independently of LBE. Under monotonic loading by using the small punch test (SPT) technique, a similar response was found in the air of uncoated and coated steels, except for the iron boride one [49]. The mechanical resistance of the iron-boride coated T91 steel was reduced compared with that of T91 steel without coating. This was attributed to the diffusion of boron in the T91 surface, resulting from the high temperature of the pack cementation. As for the mechanical response of T91 steel in LBE, the fracture of the interface between the steel and the Al-based coating promoted an effect of LBE on the 
plasticity deformation and on the damage of the T91 steel. For the others, the iron boride coating and the iron-chromium solid solution covered by a $\mathrm{M}_{23} \mathrm{C}_{6}$ carbide coating, no change in the mechanical damage by LBE was noticed. In addition to SPT, fatigue tests were performed on the T91 steel coated with a superficial $M_{23} \mathrm{C}_{6}(M=\mathrm{Cr}+\mathrm{Fe})$ compound covering a thick layer $(20 \mu \mathrm{m})$ of $\mathrm{Cr}_{1-y} \mathrm{Fe}_{y}(0<y<0.9 \mathrm{wt} . \%)$ solid solution. A beneficial effect of this coating was observed on the fatigue lives at $300{ }^{\circ} \mathrm{C}$ in LBE. The detrimental effect of LBE on fatigue lives of the T91 steel was reduced thanks to the coating [50].

From these investigations, it was concluded that even a thin coating (a few micrometers) can protect and limit corrosion without causing LME issues. Furthermore, sometimes, the presence of the coating could improve some mechanical properties in liquid metal because of a reduction of contact between the steel and the liquid metal. A coating comprising a ceramic (carbides) is a possible solution. Particular attention needs to be paid to microstructural modifications during the elaboration of the coating (high temperature, diffusion phenomena) and to the interfaces.

\section{3. $\mathrm{Al}_{2} \mathrm{O}_{3}$ Composite Coatings by Pulsed Laser Deposition}

To overcome the issue of the modification of the microstructure of martensitic steels induced by the high temperature $\mathrm{Al}_{2} \mathrm{O}_{3}$ coating process, it appeared necessary to operate at low temperature with other techniques. For that, the Pulsed Laser Deposition (PLD) technique has been employed by García Ferré et al. [51]. This technique uses high power laser pulses to melt, evaporate, and ionize material from the surface of a target. It allowed them to process at room temperature and at 400 and $600{ }^{\circ} \mathrm{C}$ by ablation of a $99.99 \%$ pure polycrystalline alumina target. They studied the corrosion resistance of T91 martensitic steel covered with a nanocrystalline $\mathrm{Al}_{2} \mathrm{O}_{3}$ /amorphous $\mathrm{Al}_{2} \mathrm{O}_{3}$ composite coating. After $500 \mathrm{~h}$ of immersion in oxygen saturated lead at $550{ }^{\circ} \mathrm{C}$, no corrosion damage was pointed out by SEM observation and Energy dispersive X-ray (EDX) maps. The results were not affected by the thickness of the coating ( 2 or $8 \mu \mathrm{m}$ ) nor by the process temperature ( 400 or $600^{\circ} \mathrm{C}$ ). García Ferré et al. also found that these hard, fully dense, and compact ceramic barriers attained an unusual ensemble of metal-like mechanical properties, superior plastic behavior, and wear resistance, as well as strong interfacial bonding [52]. The singular combination of all these features makes PLD-grown $\mathrm{Al}_{2} \mathrm{O}_{3}$ coating a suitable and promising candidate for protecting steels from corrosion in HLMs at high temperature [52].

\section{4. $\mathrm{Al}_{2} \mathrm{O}_{3}$ Composite Coatings by Sol-Gel Composite Coating Technique}

This technique has been applied by Dou et al. [53] on a base nickel alloy (Inconel 600). Although this alloy is not in the frame of the present paper, it is interesting nevertheless to mention it because the coating technique working at rather low temperature combines chemical (sol-gel) and physical (mechanical milling) methods. A mixture of sol-gel and $\alpha-\mathrm{Al}_{2} \mathrm{O}_{3}$ powders was deposited to the material by dipping several times as in conventional sol-gel method and finally sintered and dried at $400{ }^{\circ} \mathrm{C}$. This produced $\mathrm{Al}_{2} \mathrm{O}_{3}$ nano- and micro-composite coatings of about $10 \mu \mathrm{m}$ thickness. The corrosion resistance at $500{ }^{\circ} \mathrm{C}$ for $100 \mathrm{~h}$ in LBE with $7.88 \times 10^{-4} \mathrm{wt} . \%$ oxygen of a rotating specimen $(500 \mathrm{rpm})$ was evaluated. No spalling occurred on the coatings even if porosity was observed in the coating. Neither $\mathrm{Pb}$ nor Bi penetrated into the coatings, which indicates that the coatings possess an enhanced dynamic LBE corrosion resistance to LBE corrosion. This should encourage others to apply this technique on 316L and T91 steels.

\section{5. $\mathrm{Al}_{2} \mathrm{O}_{3}-\mathrm{TiO}_{2}$ Coating by Thermal Spraying Technology and Laser In-Situ Reaction Method}

Thermal spraying is a classical and widely employed technology. It consists of projecting small particles onto a cleaned and prepared surface, resulting in adhesion and formation of a continuous coating. However, the coating often exhibits low density and high porosity and contains numerous defects such as cracks or oxide inclusions. To overcome this disadvantage, Chen et al. $[54,55]$ combined successively the thermal spraying and the laser surface re-melting in-situ reaction technique in order to attempt having high 
quality coating $\mathrm{Al}_{2} \mathrm{O}_{3}-\mathrm{TiO}_{2}$ on the Chinese low activation martensitic (CLAM) steel, a steel that contains $8.91 \% \mathrm{Cr}, 1.44 \% \mathrm{~W}, 0.35 \% \mathrm{Mn}, 0.15 \% \mathrm{Ta}$, and $0.13 \% \mathrm{C}$. First, a FeCrAlTi composite powder was obtained by ball milling, heating, stirring, and drying and broken treatment of a $\mathrm{Cr}-\mathrm{Fe}, \mathrm{Fe}-\mathrm{Al}$, and $\mathrm{Ti}$ powder. The oxyacetylene flame-spraying technology was applied first to fabricate the CrFeAlTi coating, and the laser in situ reaction compound technology was then adopted to prepare the composite ceramic coating using the $\mathrm{CO}_{2}$ laser system. The sample was treated at $300{ }^{\circ} \mathrm{C}$. These combined technologies allowed them to obtain an $\mathrm{Al}_{2} \mathrm{O}_{3}-\mathrm{TiO}_{2}$ multiphase ceramic coating free of cracks or pores on the CLAM steel. A first trial in liquid lead for a duration up to $1000 \mathrm{~h}$ showed that the coating prevented $\mathrm{Pb}$ from diffusing and therefore featured potential applications in heavy liquid metals [54]. After exposure of the coated CLAM in LBE [55] without control of oxygen for $300 \mathrm{~h}$ at 450 and $550{ }^{\circ} \mathrm{C}$, neither the $\mathrm{Pb}$ signal nor Bi signal were detected in the very surface of the CLAM steel. In addition, the $\mathrm{Al}_{2} \mathrm{O}_{3}-\mathrm{TiO}_{2}$ coating exhibited a hydrophobic property on LBE, which is in favorable for LME resistance. The excellent LBE corrosion resistance of the $\mathrm{Al}_{2} \mathrm{O}_{3}-\mathrm{TiO}_{2}$ coated CLAM needs, however, to be confirmed with longer duration tests.

\subsection{AlTiN Coatings by Cathodic Arc Ion Plating}

Cathodic arc plasma is one of the ion plating PVD methods especially well developed for coating substrate with, TiN, CrN, and TiAlN films. This method has been employed by Wu et al. [56] to coat 316L stainless steel with AlTiN. First, they polished the 316L austenitic plates down to $0.25 \mu \mathrm{m}$. Before the deposition of AlTiN coating, a bonding Cr layer was deposited. This was done at $250{ }^{\circ} \mathrm{C}$ with deposition times for $\mathrm{Cr}$ and AlTiN layers of 5 and 60 min, respectively. After processing the coating, the bonding $\mathrm{Cr}$ layer had a thickness of about $0.5 \mu \mathrm{m}$, aimed at enhancing the adhesive force between the steel substrate and the upper AlTiN layer. The latter had a thickness of about $4.35 \mu \mathrm{m}$ and exhibited a dense and homogeneous structure. They observed some differences between after immersion for $500 \mathrm{~h}$ in oxygen saturated LBE at $550{ }^{\circ} \mathrm{C}$ and after immersion at $600{ }^{\circ} \mathrm{C}$. At $500{ }^{\circ} \mathrm{C}$, only the spinel consisted of the oxide layer, which though contained cracks was free of $\mathrm{Pb}$. At $600{ }^{\circ} \mathrm{C}$, a duplex-layered oxide scale was observed, in which penetration of $\mathrm{Pb}$ was detected. Nevertheless, no $\mathrm{Pb}$ and $\mathrm{Bi}$ elements were detected in the protective AlTiN coating, which remained free of cracks or holes. The corrosion resistance was attributed to the in-situ formation of a dense oxide layer consisted of $\mathrm{TiO}_{2}$ and $\alpha-\mathrm{Al}_{2} \mathrm{O}_{3}$ phases. Moreover, the oxidized coating exhibited low wettability to liquid LBE in the temperature range from 300 to $425^{\circ} \mathrm{C}$ thanks to the nanoscale clusters on the surface.

\subsection{Al-Fe Coating by Physical Vapor Deposition and Unbalanced Magnetron Sputtering}

Rivai and Takahashi [57] employed the physical vapor deposition (PVD) technic using the Unbalanced Magnetron Sputtering (UBMS) to coat steels with a layer of Al-Fe. In this technique, atoms and/or molecules of the target materials are sputtered by Ar ions in the grow discharge plasma and deposit a film on the substrate. The method was applied at $330-350{ }^{\circ} \mathrm{C}$ to coat the austenitic stainless steel SUS316FR and the martensitic steel STBA26 (9Cr1Mo) with Al-Fe. The coating originated from two plates of Al and SUS304, as the targets were bombarded by Ar ions with increased concentration in non-equilibrium magnetic fields generated by the magnetic source. Layers of 20 and $10 \mu \mathrm{m}$ for the SUS316FR and the STB26 were obtained, respectively. After immersion at $700{ }^{\circ} \mathrm{C}$ of the SUS316FR in low oxygen LBE for $1000 \mathrm{~h}$ and of the STBA26 in low oxygen lead for $500 \mathrm{~h}$, the Al-Fe coating layer could remain on the surface of both steels without penetration of LBE and lead, respectively. A very thin and stable oxide layer was formed on the surface of the coating layer and protected the surface from the corrosion attack of LBE and lead [57]. This protective coating remained efficient even under transient temperature conditions of 550-800 ${ }^{\circ} \mathrm{C}[58]$.

However, under a tensile stress condition in LBE at the low oxygen concentration (up to $5.2 \times 10^{-8}$ wt. \%) at 550 and $650{ }^{\circ} \mathrm{C}$, the corrosion behavior changed. The Fe-Al coating 
on the HCM12A steel $(11 \% \mathrm{Cr} 2 \% \mathrm{~W})$ cracked. Penetration of LBE into the base metal and the dissolution of the base metal to LBE around the cracks of the coating layer was not seen appreciably at $550{ }^{\circ} \mathrm{C}$ for $500 \mathrm{~h}$ but clearly occurred at $600{ }^{\circ} \mathrm{C}$ [59]. For the 316 stainless steel tested at $650{ }^{\circ} \mathrm{C}$, cracks were also observed with a width of $8 \mu \mathrm{m}$. LBE penetrated into the cracks and corroded the $316 \mathrm{SS}$ substrate involving both the dissolution of $\mathrm{Ni}$ and $\mathrm{Cr}$ from the steel matrix to the LBE as well as oxidation of the 316 matrix caused by oxygen in LBE. The coating layer could only reduce the surface of the matrix to be corroded by LBE and could moderate the corrosion of the depth direction but could not totally protect the material [60].

\subsection{FeAlTi Coating by Laser Melting Process}

Kurata et al. [61] employed and optimized the laser melting process with $\mathrm{Al}$, Ti, and Fe powders to coat 316 stainless steel with an Al rich layer. The optimization aimed at producing coatings free of cracks and defects, and this was obtained by using a scanning rate of $20 \mathrm{~mm} / \mathrm{min}$ and by maintaining an $\mathrm{Al}$ content less than $12 \mathrm{wt} . \%$. Coating layers $90 \mu \mathrm{m}$ thick with 5 wt. $\%-7$ wt. $\%$ Al, 3.5 wt. $\%-5.5$ wt. $\%$ Ti, 11 wt. $\%-12.5$ wt. $\%$ Cr, 7 wt. \%8 wt. $\%$ Ni, and 60 wt. $\%$ Fe were produced. During immersion at $550{ }^{\circ} \mathrm{C}$ in LBE containing $10^{-6}$ wt. $\%-10^{-4}$ wt. $\%$ of oxygen, a thin oxide covered the coating after $1000 \mathrm{~h}$ of immersion. This played the role of corrosion barrier and allowed a very good protection of 316 steel against corrosion as claimed by the authors.

\subsection{FeCrAl Coating by Low Pressure Plasma Spray Process Followed by GESA Pulse Power Process}

The GESA (Gepulste Elektronenstrahlanlage) pulse power process differs from the techniques described above by the production of a melted layer. Indeed, it involves rapid melting of a material surface layer under the influence of the electron beam, followed by rapid quenching, due to heat conduction into the unaffected bulk material. The GESA technique to modify the surface of a Fe9Cr (OPTIFER IVc) and of an austenitic steel $16 \mathrm{Cr} 15 \mathrm{Ni}$ for corrosion resistance in liquid lead under oxygen control at $550{ }^{\circ} \mathrm{C}$ appeared efficient especially when $\mathrm{Al}$ was alloyed into a surface layer of $10 \mu \mathrm{m}$ depth [62]. Indeed, no corrosion attack was observed for both alloys. Later on, Weisenburger et al. [63] employed the low pressure plasma spraying (LPPS) process followed by the GESA process for deposition of FeCrAlY at the surface of T91 martensitic steel. They obtained good quality of the surface in terms of regular thickness and absence of porosities. The coated surface layer by melting involved a large area surface to a depth of several $10 \mu \mathrm{m}$ in some $10 \mu \mathrm{s}$ without influencing the material structure of the bulk material. In the range of 4 wt. $\%-10$ wt.\% Al in the coating, a stable thin alumina scale was formed by $\mathrm{Al}$ diffusion to the surface and selective oxidation. The corrosion experiments showed good protective behavior of $\mathrm{Al}$ scales in LBE with $10^{-6} \mathrm{wt}$.\% oxygen up to $650^{\circ} \mathrm{C}$ and for exposure times up to $10,000 \mathrm{~h}[45,64]$. The protective effect of the FeCrAl coating obtained by the combination of the LPPS process with the GESA was also revealed after exposure of T91 steel in liquid lead containing $10^{-6} \mathrm{wt} . \%$ and $10^{-8} \mathrm{wt} . \%$ oxygen in a temperature range from 400 to $550{ }^{\circ} \mathrm{C}$ [65]. In addition, the GESA-modified layer at the test temperature conditions $\left(550{ }^{\circ} \mathrm{C}\right)$ and the test medium (LBE or air) did not change the LCF behavior of T91 steel [66]. The creep properties of T91 steel protected by the FeCrAlY alloys were then studied [67]. The negative influence of the liquid LBE on the creep behavior of non-protected T91 steel was stress-dependent and below a threshold stress value of $120 \mathrm{MPa}$ at $550{ }^{\circ} \mathrm{C}$, thus the influence became almost negligible. For the protected T91 steel, no signs of LBE influence were detected. The surface-modified specimens tested at high stress levels instead had creep-rupture times similar to T91 steel (original state) tested in air.

\subsection{TiC Coating by Arc Ion Plating}

$\mathrm{TiC}$ coating was achieved by Shi et al. [68] in a $0.25 \% \mathrm{C}-1.2 \% \mathrm{Si}-10.8 \% \mathrm{Cr}$ steel. The process started with a deposition of pure Ti by arc ion plating (AIP) on a mirror surface of the steel before heat treatment. Then the heat treatment was applied involving decarburiza- 
tion during the normalizing step. This produced the TiC coating with a final thickness of around $5 \mu \mathrm{m}$. However, due to the decarburization, the martensitic microstructure near the surface turned into ferrite and the decarburization layer was as thick as $0.18 \mathrm{~mm}$. The TiC coated steel was evaluated after keeping in the low and saturated oxygen LBE at $600{ }^{\circ} \mathrm{C}$ for 500,1000 , and $2000 \mathrm{~h}$. It was found that the TiC coating can effectively protect the steel from the corrosion by low oxygen LBE. It is also demonstrated by Electron Probe Micro Analysis that the $\mathrm{TiC}$ coating can strongly prevent $\mathrm{Pb}$ from penetrating. However, the thickness of the TiC coating tended to decrease with the immersion duration especially in the first $500 \mathrm{~h}$ $(2.26 \mu \mathrm{m})$ and then moderately $(1.86 \mu \mathrm{m}$ for $2000 \mathrm{~h})$. This contrasted very much with the behavior in oxygen-saturated LBE. Indeed, after exposure in oxygen-saturated static liquid $\mathrm{LBE}$ at $600{ }^{\circ} \mathrm{C}$ for $500 \mathrm{~h}$, the TiC coating transformed into two other oxides, namely $\mathrm{TiO}_{2}$ and $\mathrm{PbTiO}_{3}$. The outer layer consisted of $\mathrm{PbTiO}_{3}$, while the TiC layer was between the $\mathrm{PbTiO}_{3}$ layer and the steel substrate. The TiC coating could not protect the steel from the corrosion by the oxygen saturated LBE at $600{ }^{\circ} \mathrm{C}$.

\subsection{Nanostructured Surface Layer by Surface Mechanical Rolling Treatment}

Lu et al. [69] employed the surface mechanical rolling treatment (SMRT) to modify the surface of 9Cr2WVTa steel. The surface of the steel was impacted by WC-Co cermet balls of low velocity. This resulted in a microstructure refinement of a $80 \mu \mathrm{m}$ thick surface layer. The corrosion resistance in a stagnant LBE was investigated in regards to the effect of a pre-oxidation at $600^{\circ} \mathrm{C}$ for different durations in air. In the SMRT sample, a thin oxide scale was $0.5 \mu \mathrm{m}$ thick after exposure of $510 \mathrm{~h}$. The oxide scale was homogeneous, compact, and contained mainly $\mathrm{Mn}_{2} \mathrm{O}_{3}$ together with $\left(\mathrm{Fe}_{0.6} \mathrm{Cr}_{0.4}\right)_{2} \mathrm{O}_{3}$. In comparison with the non-treated steel, the SMRT pre-oxidized sample exhibited neither oxidation nor corrosion in LBE at $550{ }^{\circ} \mathrm{C}$ for $500 \mathrm{~h}$, but the protective effects disappeared when the immersion duration was longer than $3000 \mathrm{~h}$.

\section{Coatings Formed Following Control of the Chemical Composition of the Bulk of the Material}

The modification in the chemical composition of the material consists in adding either silicon or aluminum.

\subsection{Silicon Enriched Materials}

Kondo and Takahashi [70] found that adding $2 \%$ of silicon in a 10Cr-1Mo steel resulted in an excellent corrosion resistance in LBE at $550^{\circ} \mathrm{C}$ for $500 \mathrm{~h}$ at low oxygen concentration $\left(1.7 \times 10^{-8} \mathrm{wt} . \%\right)$ without any penetration of $\mathrm{Pb}-\mathrm{Bi}$ beneath the layer. After $2000 \mathrm{~h}$ in high oxygen concentration $\left(1 \times 10^{-6} \mathrm{wt} . \%\right) \mathrm{LBE}$, weight loss was measured, due to the formation of a thick oxide layer with poor adherence and further detachment.

Lower $\mathrm{Si}$ content in such a class of steels appeared insufficient for corrosion protection, as pointed out by Short et al. [71] for the same exposure duration. Their Fe9Cr1Mo0.32Si steel experienced selective dissolution of chromium both in reducing or oxidizing environments, at low $\left(600-615^{\circ} \mathrm{C}\right)$ and high $\left(700-715^{\circ} \mathrm{C}\right)$ temperatures. The oxide layer formed in the oxidizing conditions were insufficient against LBE dissolution. By contrast, the thin oxide scale formed in the $\mathrm{Fe}-12 \mathrm{Cr}-2 \mathrm{Si}$ acted as an excellent diffusion barrier preventing metal ions from escaping or oxygen ions from entering the metal surface. This layer consisted of principally chromia at the surface and silica between chromia and the metal.

Kurata investigated the effect of silicon in T91 steel and in 316L austenitic stainless steel [72]. He showed that the additions of $1.5 \mathrm{wt} . \% \mathrm{Si}$ to T91 steel and $2.5 \mathrm{wt} . \% \mathrm{Si}$ to 316 steel improved corrosion resistance in oxygen-saturated LBE at $550{ }^{\circ} \mathrm{C}$ for $3000 \mathrm{~h}$. However, it was not enough to prevent ferritization completely of the austenitic matrix of the 316 steel when the oxygen concentration in LBE decreased. However, as mentioned above, the modification in the protection method, here the silicon content, leading to an increase in corrosion resistance, must not negatively impact the mechanical properties of 
the material. This is one limiting advantage of silicon as an addition of $1.5 \mathrm{wt}$ \% Si to T91 steel causes rise in the ductile to brittle transition temperature (DBTT) [72].

The limiting advantage of enriched silicon steels-ferritic, martensitic, and bainitic- has been also pointed out by van den Bosch et al. [73,74] for lower test temperatures (between 300 and $375^{\circ} \mathrm{C}$ ). Despite the improved corrosion resistance of elevated Si steels in contact with liquid LBE, the bainitic S2439 (0.2 wt.\% C, 2.75 wt.\% Si, 12 wt.\% Cr, 1 wt.\% Mo, 0.3 wt. $\%$ V, 0.48 wt.\% W) and the ferritic S2440 steels ( 0.2 wt.\% C, 4.83 wt.\% Si, 14 wt.\% Cr, $1 \mathrm{wt} . \% \mathrm{Mo}, 0.3 \mathrm{wt} . \% \mathrm{~V}, 0.45 \mathrm{wt} . \% \mathrm{~W})$ were very prone to LME. Furthermore, tensile tests in argon and in LBE for a silicon-enriched high $\mathrm{Cr}$ /high creep resistant bainitic steel showed that the silicon enriched steel was very sensitive to LME.

In a comparative study on the corrosion behavior of ten stainless steels in LBE at $520{ }^{\circ} \mathrm{C}$ with dissolved oxygen content between $10^{-9}$ wt. $\%$ and $5 \times 10^{-4} \mathrm{wt}$ \% [21], two Si enriched alloys were investigated. Roy et al. pointed out that both Si-containing steels (18Cr-15Ni-3.7Si and $21 \mathrm{Cr}-11 \mathrm{Ni}-1.6 \mathrm{Si})$ exhibited very few dissolution zones even at the maximum duration $1850 \mathrm{~h}$. The average thickness of the dissolution layer in these alloys were very weak in comparison with the other steels. A 1 and $1.5 \mu \mathrm{m}$ adherent oxide layer was observed on the $21 \mathrm{Cr}-11 \mathrm{Ni}-1.6 \mathrm{Si}$ surface and on the $18 \mathrm{Cr}-15 \mathrm{Ni}-3.7 \mathrm{Si}$, respectively. Although the authors obtained a set of Ni-containing alloys presenting promising corrosion behavior, they pointed out the necessity of performing long terms experiments and controlling the Si content to avoid LME.

It turns out that an improvement in corrosion resistance by Si-enrichment of numerous steels including T91 steel and $316 \mathrm{~L}$ steel is indeed observed. However, for ferritic matrix steel, the positive effect is counterbalanced by a spoiling of their good mechanical properties, which is not acceptable. Therefore, at least for ferritic matrix steels, one had to turn to the other candidate element, aluminum.

\subsection{Aluminum Enriched Materials}

High chromium ferritic stainless steels, the NTK04L steel (18Cr-3Al) and the Recloy10 steel (18Cr-1Si-1Al) were investigated at $550{ }^{\circ} \mathrm{C}$ up to $1000 \mathrm{~h}$ in LBE with an oxygen concentration of $1.7 \times 10^{-8}$ wt. $\%$ and up to $2000 \mathrm{~h}$ in LBE with an oxygen concentration of $1 \times 10^{-6}$ wt.\% by Kondo and Takahashi [70]. An Al-enriched single layer stuck to the matrix was formed on the surface of the NTK04L steel, which protected the matrix from not only the liquid metal corrosion but also the oxidation corrosion, since this layer had oxidation resistance in the $\mathrm{Pb}-\mathrm{Bi}$ flow at high oxygen concentration. The weight of the NTK04L steel specimen decreased slightly with exposure time, due to corrosion. A single Al- and Si-enriched layer was formed on the surface of the Recloy10 steel and even after $2000 \mathrm{~h}$ in LBE, the weight of the Recloy10 steel did not decrease due to the absence of corrosion. Higher Cr steels alloyed with aluminum were investigated by Lim et al. [75,76], the Kanthal-AF (a Fe22Cr5Al alloy containing small amount of yttrium and zirconium), the MA956 (Fe18Cr4.8Al) and PM2000 (Fe19Cr5.7Al) which are both yttrium-oxide dispersion strengthened (ODS) steels. From their tests at 500 and $550{ }^{\circ} \mathrm{C}$, different morphologies of coating layers were observed and thus different corrosion resistances to LBE. In $500{ }^{\circ} \mathrm{C}$ tests, thin $\mathrm{Al}_{2} \mathrm{O}_{3}$ layers were formed on the surface of all tested materials, and there was no dissolution attack by LBE. The existence of the chromium sulfide $(\mathrm{CrS})$ island at the $\mathrm{Al}_{2} \mathrm{O}_{3}$ layer/metal interface was found. The inner $\mathrm{Al}_{2} \mathrm{O}_{3}$ layer formed on MA956, while the inner $\mathrm{Al}_{2} \mathrm{O}_{3}$ layer did not form on Kanthal-AF and PM2000. At $550{ }^{\circ} \mathrm{C}$, it was found that LBE penetrates into the metal of Kanthal-AF through the damaged oxide layer and along the grain boundary of the metal. The penetrated depth of LBE was about $20 \mu \mathrm{m}$. In case of ODS materials (MA956, PM2000), the penetration of LBE into the metal was not observed. It was concluded that FeCrAl ODS steels (PM2000, MA956) are superiorly resistant to corrosion compared to the FeCrAl ferritic steel (Kanthal-AF) in LBE at higher temperature. Baker and Brewer [77] addressed the issue of LME in MA956 steel. By using slow strain rate tests, they found immunity for this alloy to LME by lead and LBE without control of oxygen at 328 and $150{ }^{\circ} \mathrm{C}$ respectively. 
Even if these materials exhibit interesting corrosion behavior in LBE, they contain costly chemical elements and can be susceptible to embrittlement in specific temperature regions. To suppress the cost drawback, low chromium ferritic steels (Fe-10Cr-4Al) are being considered as potential candidates. Dömstedt et al. elaborated alloys with the aim to be able to operate at temperatures higher than $550{ }^{\circ} \mathrm{C}$ [78]. After exposure in stagnant liquid lead with and without oxygen at $750{ }^{\circ} \mathrm{C}$ for up to $1970 \mathrm{~h}$, the steels presented a good corrosion resistance in liquid lead with minor oxidation and no dissolution. However, it will be necessary to check their LME sensitivity in this range of temperature considering LME evidence at $350{ }^{\circ} \mathrm{C}$. Indeed, by using slow strain rate tests, Gong et al. pointed out LME of $\mathrm{Fe}-10 \mathrm{Cr}-4 \mathrm{Al}$ at $350^{\circ} \mathrm{C}$ in LBE containing low as well as high oxygen [79]. Transgranular cleavage and intergranular cracking were the major fracture modes. The double-layer oxide scale consisting of magnetite and Al-rich spinel was fragmented, indicative of a brittle nature.

Nevertheless, the intensive research carried out inside the European projects (TECLA, DEMETRA, MatISSE ... ) led to the conclusions that the reported cases of LME in ferritic/martensitic steels suggest to limit their use as structural materials in contact with liquid LBE or liquid lead. Therefore, the use of austenitic steels (e.g., 15-15Ti and 316 steels) have received fresh attention while keeping in mind the issue of the selective dissolution of nickel. As for ferritic steels, aluminum was added to form a protective alumina oxide for corrosion mitigation in LBE or liquid lead. Enriched aluminum austenitic stainless steels are often referred to as AFA which stands for alumina-forming austenitic (AFA). As pointed out above, fine tuning of the chemical composition is necessary to balance corrosion resistance with stability of the austenitic phase.

In their comparative study on stainless steels in LBE at $520{ }^{\circ} \mathrm{C}$ with dissolved oxygen content between $10^{-9}$ wt. $\%$ and $5 \times 10^{-4}$ wt. $\%$, Roy et al. [21] included the $14 \mathrm{Cr}-25 \mathrm{Ni}-$ 3.5Al AFA steel. After $1850 \mathrm{~h}$, this AFA exhibited few dissolution zones. Oxidation seemed to be the dominant mechanism even if the corrosion layer did not cover uniformly the steel surface. The presence of adherent and non-adherent oxide layers even seems to highlight a mechanism of oxide dissolution. Ejenstam and Szakalos [80] did the same task with the 14Cr14Ni2.5Al AFA and 14Cr20Ni2.5Al AFA steels and conventional 316L and 15-15Ti stainless steels at $550{ }^{\circ} \mathrm{C}$ in liquid lead $\left(10^{-7} \mathrm{wt}\right.$.\% oxygen) for durations up to one year. As expected, dissolution local attacks occurred on the 316 L and on the 15-15Ti but also on the $14 \mathrm{Cr} 20 \mathrm{Ni} 2.5 \mathrm{Al}$ AFA. In contrast, $14 \mathrm{Ni}$ AFA did not suffer from dissolution attack tanks to the formation of a thin protective $(<100 \mathrm{~nm})$ Al rich oxide after one year of exposure in liquid lead at $550{ }^{\circ} \mathrm{C}$. However, the austenitic structure transformed into ferrite. In view of maintaining the austenitic structure, the research of Shi et al. [81] aimed at determining the concentration ranges of the alloying elements $(\mathrm{Cr}, \mathrm{Al}$, and $\mathrm{Ni}$ ), for which quaternary FeCrAlNi-based model alloys exhibit corrosion resistance in liquid lead at 600 and $550{ }^{\circ} \mathrm{C}$ (oxygen contain equal to $10^{-6} \mathrm{wt}$.\%), while preserving the austenitic structure as the alloy matrix. A passivated scale constituted by $\mathrm{Cr}_{2} \mathrm{O}_{3}$ and $\mathrm{Al}_{2} \mathrm{O}_{3}$ were formed. They found that for the passivating scale formation, while preserving the austenitic structure of the alloy matrix in AFA, the composition range Fe-(20-29)Ni-(15.2-16.5) Cr-(2.3-4.3)Al (wt.\%) should be designed for applications in $\mathrm{Pb}$ and $\mathrm{Pb}$-based alloy environments up to $600{ }^{\circ} \mathrm{C}$. In case of application temperatures less than $550{ }^{\circ} \mathrm{C}$, the critical $\mathrm{Cr}$ content was found at $14.4 \mathrm{wt}$ \%. However, if the optimization of the chemical composition allowed maintaining the austenitic structure at the surface of the material, $\mathrm{Ni}_{3}(\mathrm{Al}, \mathrm{Fe})$ precipitated in the bulk after exposure of $1000 \mathrm{~h}$ at $600{ }^{\circ} \mathrm{C}$. To check the real impact of the presence of the ferritic phase in an austenitic matrix on the corrosion resistance, Chen et al. elaborated a duplex steel $18 \mathrm{Ni}-16 \mathrm{Cr}-4 \mathrm{Al}-2 \mathrm{Mo}-0.4 \mathrm{Nb}$ (in wt.\%) with 75 vol. $\%$ austenitic phase and 25 vol.\% ferritic phase [82]. At $700{ }^{\circ} \mathrm{C}$, for $1000 \mathrm{~h}$ in liquid lead with low oxygen content $\left(10^{-9} \mathrm{wt} . \%\right)$, obvious lead penetration combined with nickel dissolution was observed. With a more important content of oxygen $\left(10^{-6} \mathrm{wt} . \%\right)$, the steel was protected by a thin oxide layer. After $1000 \mathrm{~h}$ at $700{ }^{\circ} \mathrm{C}$, the $\mathrm{NiAl}$ and Laves phases were observed. They are known to be 
detrimental to the mechanical properties of traditional steels but were not of concern for this study.

Since nickel is a critical element of stainless steels regarding corrosion, Wang et al. [83] paid attention to the corrosion behavior of Al-added high manganese steels, since manganese is known to stabilize the austenitic structure, as nickel does. They investigated $21.5 \% \mathrm{Mn} 1 \% \mathrm{Cr}$ steels with $5 \%, 6 \%$, and $7 \%$ of aluminum in saturated oxygen LBE or low oxygen LBE (down to $1.6 \times 10^{-8}$ wt. $\%$ ) at $450{ }^{\circ} \mathrm{C}$ for $430 \mathrm{~h}$. They showed that the oxide layer was not protective against saturated oxygen LBE but became protective in low oxygen LBE. They recommended a content of $7 \mathrm{wt}$ \% of aluminum to expect reliable protection of the steel.

\section{Conclusions}

Austenitic stainless steels and ferritic-martensitic are material candidates to be employed in Gen IV nuclear reactors and accelerator-driven systems. They will be in contact with liquid lead and LBE in a temperature range from 300 to $550{ }^{\circ} \mathrm{C}$. Corrosion and liquid metal embrittlement have to be taken into account for the reliability and safety of these plants. The intensive research conducted during the last three decades has confirmed the choice of these materials and the limits to their use. To control degradation by liquid lead or LBE, attention has to be paid to the surface of the structural alloys in contact with the liquid metals.

The present review points out the strong efforts paid to the mitigation of corrosion. The search for a protective barrier between the steel substrate and the liquid metal is conducted according two routes: the formulation of a protective barrier and the choice of the technological process to coat the steel substrate and the optimization of the chemical composition of the steel which reacts into the liquid metal to form a "natural" protective oxide. The operating conditions of the investigated coating processes allowed working at low as as well high temperature, and thanks to the use of some high technology coating processes, allowed optimizing the adhesion of the coating. Resistance to corrosion in lead or LBE can be observed for short time durations but needs to be confirmed especially by longer term experiments and by additional mechanical testing. The formulation of chemical composition of the steel to form "natural" protection requires extended investigation. However, the identification of the detrimental elements such as silicon and of advantageous ones such as manganese allows going into this direction. Nevertheless, this second route seems to be less open than the former one.

Author Contributions: J.-B.V. and I.P.S. contributed to the collecting and analysis of the selected papers included in the present review paper. J.-B.V. wrote the review paper. J.-B.V. and I.P.S. read and approved the final manuscript. All authors have read and agreed to the published version of the manuscript.

Funding: The research was supported by our institutes and partially by the European Union. This work was conducted in GEMMA project of the European Commission HORIZON 2020 Framework Program under grant agreement No. 755269.

Institutional Review Board Statement: Not applicable.

Informed Consent Statement: Not applicable.

Data Availability Statement: Publicly available datasets were analyzed in this study. This data can be found in each reference below.

Conflicts of Interest: The authors declare no conflict of interest.

\section{References}

1. Kalantar-Zadeh, K.; Tang, J.; Daeneke, T.; O’Mullane, A.P.; Stewart, L.A.; Liu, J.; Majidi, C.; Ruoff, R.S.; Weiss, P.S.; Dickey, M.D. Emergence of liquid metals in nanotechnology. ACS Nano 2019, 13, 7388-7395. [CrossRef]

2. Mansur, L.K. Materials research and development for the spallation neutron source mercury target. J. Nucl. Mater. 2003, 318, 14-25. [CrossRef] 
3. Takada, H.; Haga, K.; Teshigawara, M.; Aso, T.; Meigo, S.-I.; Kogawa, H.; Naoe, T.; Wakui, T.; Ooi, M.; Harada, M.; et al. Materials and life science experimental facility at the Japan Proton Accelerator Research Complex I: Pulsed spallation neutron source. Quantum Beam Sci. 2017, 1, 8. [CrossRef]

4. Frazer, D.; Stergar, E.; Cionea, C.; Hosemann, P. Liquid metal as a heat transport fluid for thermal solar power applications. Energy Procedia 2014, 49, 627-636. [CrossRef]

5. Lorenzin, N.; Abánades, A. A review on the application of liquid metals as heat transfer fluid in concentrated solar power technologies. Int. J. Hydrogen Energy 2016, 41, 6990-6995. [CrossRef]

6. Popovic, M.P.; Bolind, A.M.; Cionea, C.; Hosemann, P. Liquid lead-bismuth eutectic as a coolant in generation IV nuclear reactors and in high temperature solar concentrator applications: Characteristics, challenges, issues. Contemp. Mater. 2015, 6, 20-34. [CrossRef]

7. Sakamoto, Y.; Garnier, J.C.; Rouaul, J.; Grandy, C.; Fanning, T.; Hill, R.; Chikazawa, Y.; Kotake, S. Selection of sodium coolant for fast reactors in the US, France and Japan. Nucl. Eng. Des. 2013, 254, 194-217. [CrossRef]

8. Horiike, H.; Konishi, S.; Kondo, H.; Yamaguchi, A. Liquid metal cooling issues for fusion and fission. Fusion Eng. Des. 2008, 83, 943-947. [CrossRef]

9. Latge, C.; Wohlmuther, M.; Dai, Y.; Gavillet, D.; Gessi, A.; Guertin, A.; Hammer, B.; Heinitz, S.; Henry, J.; Konstantinovic, M.; et al. MEGAPIE: The world's first high-power liquid metal spallation neutron source. In Thorium Energy for the World; Revol, J.P., Bourquin, M., Kadi, Y., Lillestol, E., de Mestral, J.C., Samec, K., Eds.; Springer: Cham, Switzerland, 2016. [CrossRef]

10. Toshinsky, G.I.; Dedul, A.V.; Komlev, O.G.; Kondaurov, A.V.; Petrochenko, V.V. Lead-bismuth and lead as coolants for fast reactors. World J. Nucl. Sci. Technol. 2020, 10, 65-75. [CrossRef]

11. Ballinger, R.G.; Lim, J. An overview of corrosion issues for the design and operation of high-temperature lead and lead-bismuth eutectic cooled reactors systems. Nucl. Technol. 2004, 147, 418-435. [CrossRef]

12. Sobolev, V. Thermophysical properties of lead and lead-bismuth eutectic. J. Nucl. Mater. 2007, 362, 235-247. [CrossRef]

13. Takahashi, M.; Sa, R.; Pramutadi, A.; Yamaki-Irisawa, E. Overview of recent studies related to lead-alloy-cooled fast reactors. Nucl. Sci. Eng. 2012, 1448, 39-49. [CrossRef]

14. Zhang, J. Lead-bismuth eutectic (LBE): A coolant candidate for Gen. IV, advanced nuclear reactor concepts. Adv. Eng. Mater. 2014, 16, 349-356. [CrossRef]

15. Courouau, J.-L.; Feron, D. Corrosion of structural materials by liquid metals used fusion, fission and spallation. In Proceedings of the 1st IAEA Workshop on Challenges for Coolants in Fast Spectrum System, Vienne, Austria, 5-7 July 2017.

16. Cheng, J.; Zhu, S.; Tan, H.; Yu, Y.; Yang, J.; Liu, W. Lead-bismuth liquid metal: Lubrication behaviors. Wear 2019, 403-431, 94-99. [CrossRef]

17. Fazio, C.; Balbaud, F. Corrosion phenomena induced by liquid metals in Generation IV reactors. In Structural Materials for Generation IV Nuclear Reactors; Yvon, P., Ed.; Elsevier: Amsterdam, The Netherlands, 2017; Chapter 2; pp. 23-74. [CrossRef]

18. Balbaud-Celerier, F.; Deloffre, P.; Terlain, A.; Rusanov, A. Corrosion of metallic materials in flowing liquid lead-bismuth. J. Phys. IV Fr. 2002, 12, 177-190. [CrossRef]

19. Tian, S.J. Growth and exfoliation behavior of the oxide scale on $316 \mathrm{~L}$ and T91 in flowing liquid lead-bismuth eutectic at $480{ }^{\circ} \mathrm{C}$. Oxid. Met. 2020, 93, 183-194. [CrossRef]

20. Tsisar, V.; Schroer, C.; Wedemeyer, O.; Skrypnik, A.; Konys, J. Corrosion behavior of austenitic steels 1.4970, 316L and 1.4571 in flowing LBE at 450 and $550{ }^{\circ} \mathrm{C}$ with $10^{-7}$ mass \% dissolved oxygen. J. Nucl. Mater. 2014, 454, 332-342. [CrossRef]

21. Roy, M.; Martinelli, L.; Ginestar, K.; Favergeon, J.; Moulin, G. Dissolution and oxidation behaviour of various austenitic steels and Ni rich alloys in lead-bismuth eutectic at $520^{\circ} \mathrm{C}$. J. Nucl. Mater. 2016, 468, 153-163. [CrossRef]

22. Martinelli, L.; Courouau, J.-L.; Balbaud-Célérier, F. Oxidation of steels in liquid lead bismuth: Oxygen control to achieve efficient corrosion protection. Nucl. Eng. Des. 2011, 241, 1288-1294. [CrossRef]

23. Ye, Z.; Wang, P.; Dong, H.; Li, D.; Zhang, Y.; Li, Y. Oxidation mechanism of T91 steel in liquid lead-bismuth eutectic: With consideration of internal oxidation. Nat. Sci. Rep. 2016, 6, 35268. [CrossRef]

24. Duchoň, J.; Halodová, P.; Lorinčínk, J.; Di Gabriele, F.; Hojná, A. Characterization of oxides by advanced techniques. Acta Metall. Slovaca 2018, 24, 13-19. [CrossRef]

25. Tsisar, V.; Gavrilov, S.; Schroer, C.; Stergar, E. Long-term corrosion performance of T91 ferritic/martensitic steel at $400{ }^{\circ} \mathrm{C}$ in flowing $\mathrm{Pb}-\mathrm{Bi}$ eutectic with $2 \times 10^{-7}$ mass\% dissolved oxygen. Corros. Sci. 2020, 174, 108852. [CrossRef]

26. Barbier, F.; Rusanov, A. Corrosion behavior of steels in flowing lead-bismuth. J. Nucl. Mater. 2001, 296, 231-236. [CrossRef]

27. Kurata, Y.; Futakawa, M. Excellent corrosion resistance of $18 \mathrm{Cr}-20 \mathrm{Ni}-5 \mathrm{Si}$ steel in liquid Pb-Bi. J. Nucl. Mater. 2004, 325, 217-222. [CrossRef]

28. Hojná, A.; Halodová, P.; Chocholoušek, M.; Špirit, Z.; Rozumová, L. Environmentally assisted cracking of T91 ferritic-martensitic steel in heavy liquid metals. Corros. Rev. 2019, 38. [CrossRef]

29. Yamaki, E.; Ginestar, K.; Martinelli, L. Dissolution mechanism of 316L in lead-bismuth eutectic at $500{ }^{\circ} \mathrm{C}$. Corros. Sci. 2011, 53, 3075-3085. [CrossRef]

30. Klok, O.; Lambrinou, K.; Gavrilov, S.; Lim, J.; De Graeve, I. Effect of LBE oxygen concentration on the onset of dissolution corrosion in 316L austenitic stainless steel at $450{ }^{\circ} \mathrm{C}$. J. Nucl. Eng. Radiat. Sci. 2018, 4, 031019. [CrossRef]

31. Kurata, Y. Corrosion behavior of cold-worked austenitic stainless steels in liquid lead-bismuth eutectic. J. Nucl. Mater. 2014, 448, 239-249. [CrossRef] 
32. Lambrinou, K.; Charalampopoulou, E.; Van der Donck, T.; Delville, R.; Schryvers, D. Dissolution corrosion of 316L austenitic stainless steels in contact with static liquid lead-bismuth eutectic (LBE) at $500{ }^{\circ} \mathrm{C}$. J. Nucl. Mater. 2017, 490, 9-27. [CrossRef]

33. Yurechko, M.; Schroer, C.; Skrypnik, A.; Wedemeyer, O.; Tsisar, V.; Konys, J. Steel T91 subjected to static stress in lead-bismuth eutectic at $450-550{ }^{\circ} \mathrm{C}$ and low oxygen concentration. J. Nucl. Mater. 2018, 512, 423-439. [CrossRef]

34. Martinelli, L.; Ginestar, K.; Botton, V.; Delisle, C.; Balbaud-Célérier, F. Corrosion of T91 and pure iron in flowing and static Pb-Bi alloy between $450^{\circ} \mathrm{C}$ and $540{ }^{\circ} \mathrm{C}$ : Experiments, modelling and mechanism. Corros. Sci. 2020, 176, 108897. [CrossRef]

35. Kalkhof, D.; Grosse, M. Influence of PbBi environment on the low-cycle fatigue behavior of SNS target container materials. J. Nucl. Mater. 2003, 318, 143-150. [CrossRef]

36. Vogt, J.-B.; Proriol Serre, I. Fatigue behaviour of a martensitic and an austenitic steel in heavy liquid metals. Proc. Eng. 2013, 55, 812-818. [CrossRef]

37. Serre, I.; Vogt, J.-B. Heat treatment effect of T91 martensitic steel on liquid metal embrittlement. J. Nucl. Mater. 2008, 376, 330-335. [CrossRef]

38. Long, B.; Tong, Z.; Gröschel, F.; Dai, Y. Liquid Pb-Bi embrittlement effects on the T91 steel after different heat treatments. J. Nucl. Mater. 2008, 377, 219-224. [CrossRef]

39. Gong, X.; Marmy, P.; Qin, L.; Verlinden, B.; Wevers, M.; Seefeldt, M. Effect of liquid metal embrittlement on low cycle fatigue properties and fatigue crack propagation behaviour of a modified $9 \mathrm{Cr}-1 \mathrm{Mo}$ ferritic-martensitic steel in an oxygen-controlled lead-bismuth eutectic environment at $350^{\circ} \mathrm{C}$. MSE A 2014, 618, 406-415. [CrossRef]

40. Gong, X.; Marmy, P.; Qin, L.; Verlinden, B.; Wevers, M.; Seefeldt, M. Temperature dependence of liquid metal embrittlement susceptibility of a modified $9 \mathrm{Cr}-1 \mathrm{Mo}$ steel under low cycle fatigue in lead-bismuth eutectic at $160-450{ }^{\circ} \mathrm{C}$. J. Nucl. Mater. 2016, 468, 289-298. [CrossRef]

41. Vogt, J.-B.; Bouquerel, J.; Carle, C.; Proriol-Serre, I. Stability of fatigue cracks at $350{ }^{\circ} \mathrm{C}$ in air and in liquid metal in T91 martensitic steel. Int. J. Fatigue 2020, 130, 105265. [CrossRef]

42. Jianu, A.; Müller, G.; Weisenburger, A.; Heinzel, A.; Fazio, C.; Markov, V.G.; Kashtanov, A.D. Creep-to-rupture tests of T91 steel in flowing Pb-Bi eutectic melt at $550{ }^{\circ} \mathrm{C}$. J. Nucl. Mater. 2009, 394, 102-108. [CrossRef]

43. Strafella, A.; Coglitore, A.; Fabbri, P.; Salernitano, E. 15-15Ti(Si) austenitic steel: Creep behaviour in hostile environment. Frattura ed Integrità Strutturale 2017, 42, 352-365. [CrossRef]

44. Gong, X.; Yang, Z.; Deng, Y.; Xiao, J.; Wang, H.; Yu, Z.; Yin, Y. Creep failure of a solution-annealed 15-15Ti steel exposed to stagnant lead-bismuth eutectic at 550 and $600{ }^{\circ} \mathrm{C}$. MSE A 2020, 798, 140230. [CrossRef]

45. Weisenburger, A.; Schroer, C.; Jianu, A.; Heinzel, A.; Konys, J.; Steiner, H.; Muller, G.; Fazio, C.; Gessi, A.; Babayan, S.; et al. Long term corrosion on T91 and AISI1 316L steel in flowing lead alloy and corrosion protection barrier development: Experiments and models. J. Nucl. Mater. 2011, 415, 260-269. [CrossRef]

46. Tian, S.J.; Jiang, Z.Z.; Luo, L. Oxidation behavior of T91 steel in flowing oxygen-containing lead-bismuth eutectic at $500{ }^{\circ} \mathrm{C}$. Mater. Corros. 2016, 67, 1274-1285. [CrossRef]

47. Deloffre, P.; Balbaud-Célérier, F.; Terlain, A. Corrosion behaviour of aluminized martensitic and austenitic steels in liquid Pb-Bi. J. Nucl. Mater. 2004, 335, 180-184. [CrossRef]

48. Ledoux, X.; Vilasi, M.; Mathieu, S.; Panteix, J.P.; Del-Gallo, P.; Wagner, M. Development of chromium and aluminum coatings on superalloys by pack-cementation technique. Adv. Mater. Res. 2011, 278, 491-496. [CrossRef]

49. Proriol Serre, I.; Diop, I.; David, N.; Vilasi, M.; Vogt, J.-B. Mechanical behavior of coated T91 steel in contact with lead-bismuth liquid alloy at $300^{\circ}$ C. Surf. Coat. Technol. 2011, 205, 4521-4527. [CrossRef]

50. Vogt, J.-B.; Proriol-Serre, I.; Martinelli, L.; David, N.; Vilasi, M. Fatigue resistance in liquid lead-bismuth eutectic alloy of T91 steel. In Proceedings of the ICAPP 2011: Performance and Flexibility-The Power of Innovation, Nice, France, 2-5 May 2011; Paper 11328.

51. García Ferré, F.; Bertarelli, E.; Chiodoni, A.; Carnelli, D.; Gastaldi, D.; Vena, P.; Beghi, M.G.; Di Fonzo, F. The mechanical properties of a nanocrystalline $\mathrm{Al}_{2} \mathrm{O}_{3} / \mathrm{a}-\mathrm{Al}_{2} \mathrm{O}_{3}$ composite coating measured by nanoindentation and Brillouin spectroscopy. Acta Mater. 2013, 61, 2662-2670. [CrossRef]

52. García Ferré, F.; Ormellese, M.; Di Fonzo, F.; Beghi, M.G. Advanced $\mathrm{Al}_{2} \mathrm{O}_{3}$ coatings for high temperature operation of steels in heavy liquid metals: A preliminary study. Corros. Sci. 2013, 77, 375-378. [CrossRef]

53. Dou, P.; Kasada, R. Preliminary study on nano- and micro-composite sol-gel based alumina coatings on structural components of lead-bismuth eutectic cooled fast breeder reactors. J. Nucl. Mater. 2011, 409, 177-182. [CrossRef]

54. Chen, Y.; Hu, L.; Qiu, C.; Huang, Q. Characterization of multiphase ceramic coatings fabricated via laser in situ reaction technology. Surf. Eng. 2018, 34, 301-308. [CrossRef]

55. Chen, Y.; Hu, L.; Qiu, C.; He, B.; Zhou, J.; Zhao, J.; Li, Y. Influence of LBE Temperatures on the microstructure and properties of crystalline and amorphous multiphase ceramic coatings. Coatings 2019, 9, 543. [CrossRef]

56. Wu, Z.Y.; Zhao, X.; Liu, Y.; Cai, Y.; Li, J.Y.; Chen, H.; Wan, Q.; Yang, D.; Tan, J.; Liu, H.D.; et al. Lead-bismuth eutectic (LBE) corrosion behavior of AlTiN coatings at 550 and $600{ }^{\circ} \mathrm{C}$. J. Nucl. Mater. 2020, 539, 152280. [CrossRef]

57. Rivai, A.K.; Takahashi, M. Corrosion investigations of Al-Fe-coated steels, high Cr steels, refractory metals and ceramics in lead alloys at $700{ }^{\circ} \mathrm{C}$. J. Nucl. Mater. 2010, 398, 146-152. [CrossRef]

58. Rivai, A.K.; Takahashi, M. Corrosion characteristics of materials in Pb-Bi under transient temperature conditions. J. Nucl. Mater. 2010, 398, 139-145. [CrossRef] 
59. Yamaki, E.; Takahashi, M. Corrosion resistance of Fe-Al-alloy-coated ferritic/martensitic steel under bending stress in hightemperature lead-bismuth eutectic. J. Nucl. Sci. Technol. 2011, 48, 797-804. [CrossRef]

60. Yamaki-Irisawa, E.; Numata, S.; Takahashi, M. Corrosion behavior of heat-treated Fe-Al coated steel in lead-bismuth eutectic under loading. Prog. Nucl. Energy 2011, 53, 1066-1072. [CrossRef]

61. Kurata, Y.; Yokota, H.; Suzuki, T. Development of aluminum-alloy coating on type 316SS for nuclear systems using liquid lead-bismuth. J. Nucl. Mater. 2012, 424, 237-246. [CrossRef]

62. Müller, G.; Schumacher, G.; Zimmermann, F. Investigation on oxygen controlled liquid lead corrosion of surface treated steels. J. Nucl. Mater. 2000, 278, 85-95. [CrossRef]

63. Weisenburger, A.; Heinzel, A.; Müller, G.; Muscher, H.; Rousanov, A. T91 cladding tubes with and without modified FeCrAlY coatings exposed in LBE at different flow, stress and temperature conditions. J. Nucl. Mater. 2008, 376, 274-281. [CrossRef]

64. Weisenburger, A.; Müller, G.; Heinzel, A.; Jianu, A.; Muscher, H.; Kieser, M. Corrosion, Al containing corrosion barriers and mechanical properties of steels foreseen as structural materials in liquid lead alloy cooled nuclear systems. NED 2011, 241, 1329-1334. [CrossRef]

65. Fetzer, R.; Weisenburger, A.; Jianu, A.; Müller, G. Oxide scale formation of modified FeCrAl coatings exposed to liquid lead. Corros. Sci. 2012, 55, 213-218. [CrossRef]

66. Weisenburger, A.; Heinzel, A.; Fazio, C.; Müller, G.; Markow, V.G.; Kastanov, A.D. Low cycle fatigue tests of surface modified T91 steel in $10^{-6}$ wt.\% oxygen containing Pb45Bi55 at $550{ }^{\circ} \mathrm{C}$. J. Nucl. Mater. 2008, 377, 261-267. [CrossRef]

67. Weisenburger, A.; Jianu, A.; An, W.; Fetzer, R.; Del Giacco, M.; Heinzel, A. Creep, creep-rupture tests of Al-surface-alloyed T91 steel in liquid lead bismuth at 500 and $550{ }^{\circ} \mathrm{C}$. J. Nucl. Mater. 2012, 431,77-84. [CrossRef]

68. Shi, Q.; Yan, W.; Sha, W.; Wang, W.; Shan, Y.-Y.; Yang, K. Corrosion resistance of self-growing TiC coating on SIMP steel in LBE at $600{ }^{\circ}$ C. Mater. Corros. 2016, 67, 1204-1212. [CrossRef]

69. Lu, Y.H.; Wang, Z.B.; Song, Y.Y.; Rong, L.J. Effects of pre-formed nanostructured surface layer on oxidation behaviour of 9Cr2WVTa steel in air and liquid Pb-Bi eutectic alloy. Corros. Sci. 2016, 102, 301-309. [CrossRef]

70. Kondo, M.; Takahashi, M. Corrosion resistance of Si- and Al-rich steels in flowing lead-bismuth. J. Nucl. Mater. 2006, 356, $203-212$. [CrossRef]

71. Short, M.P.; Ballinger, R.G.; Hänninen, H.E. Corrosion resistance of alloys F91 and Fe-12Cr-2Si in lead-bismuth eutectic up to $715^{\circ}$ C. J. Nucl. Mater. 2013, 434, 259-281. [CrossRef]

72. Kurata, Y.; Futakawa, M.; Saito, S. Corrosion experiments and materials developed for the Japanese HLM systems. J. Nucl. Mater. 2011, 424, 254-259. [CrossRef]

73. Van Den Bosch, J.; Hosemann, P.; Almazouzi, A.; Maloy, S.A. Liquid metal embrittlement of silicon enriched steel for nuclear applications. J. Nucl. Mater. 2010, 398, 116-121. [CrossRef]

74. Van Den Bosch, J.; Coen, G.; Hosemann, P.; Maloy, S.A. On the LME susceptibility of Si enriched steels. J. Nucl. Mater. 2012, 429, 105-112. [CrossRef]

75. Lim, J.; Nam, H.O.; Hwang, I.; Soon, K.; Ji, H. Study of early corrosion behaviors of FeCrAl alloys in liquid lead-bismuth eutectic environments. J. Nucl. Mater. 2010, 407, 205-210. [CrossRef]

76. Lim, J.; Hwang, I.; Kim, J. Design of alumina forming FeCrAl steels for lead or lead-bismuth cooled fast reactors. J. Nucl. Mater. 2013, 441, 650-660. [CrossRef]

77. Baker, B.W.; Brewer, L.N. Evaluation of liquid metal embrittlement susceptibility of oxide. J. Nucl. Mater. 2014, 453, 239-246. [CrossRef]

78. Dömstedt, P.; Lundberg, M.; Szakalos, P. Corrosion studies of low-alloyed FeCrAl steels in liquid lead at $750{ }^{\circ} \mathrm{C}$. Oxid. Met. 2019, 91, 511-524. [CrossRef]

79. Gong, X.; Chen, J.; Hu, F.; Xiang, C.; Yu, Z.; Xiao, J.; Wang, H.; Gong, H.; Wang, H.; Liu, C.; et al. Liquid metal embrittlement of an Fe10Cr4Al ferritic alloy exposed to oxygen-depleted and -saturated lead-bismuth eutectic at $350{ }^{\circ}$ C. Corros. Sci. 2020, 165,108364 . [CrossRef]

80. Ejenstam, E.; Szakálos, P. Long term corrosion resistance of alumina forming austenitic stainless steels in liquid lead. J. Nucl. Mater. 2015, 461, 164-170. [CrossRef]

81. Shi, H.; Jianu, A.; Weisenburger, A.; Tang, C.; Heinzel, A.; Fetzer, R.; Lang, F.; Stieglitz, R.; Müller, G. Corrosion resistance and microstructural stability of austenitic Fe-Cr-Al-Ni model alloys exposed to oxygen-containing molten lead. J. Nucl. Mater. 2019, 524, 177-190. [CrossRef]

82. Chen, L.; Wang, M.; Tsisar, V.; Schroer, C.; Zhou, Z. Investigation of microstructure and liquid lead corrosion behavior of a Fe-18Ni-16Cr-4Al base alumina-forming austenitic stainless steel. Mater. Res. Express 2020, 7, 026533. [CrossRef]

83. Wang, H.; Yu, H.; Kondo, S.; Okubo, N.; Kasada, R. Corrosion behaviour of Al-added high Mn austenitic steels in molten lead. Corros. Sci. 2020, 175, 108864. [CrossRef] 